\title{
Joint Space Gap of Leptin-Def. ob/ob Mice in Response to Loading
}

\section{Gelenkspaltweite Leptin-def. Mäuse unter biomechanischer Belastung}

Das Hormon Leptin reguliert die Reifung und Entwicklung des Knochens. Unbekannt ist der Einfluß auf die Gelenke. Ziel der Studie war es, ohne die hormonelle Wirkung von Leptin die Auswirkung des Körpergewichtes auf den Gelenkspalt von Hüft- und Kniegelenk während des Wachstums zu untersuchen. Material und Methode: Je $20 \mathrm{C} 57 \mathrm{BL} / 6 \mathrm{~J}-\mathrm{Lep}^{\mathrm{ob}}$ (ob/ob) weibliche leptindefiziente Mäuse wurden in eine Gruppe mit freier Futtermenge (Gruppe A) und eine Gruppe mit einer kontrollierter Futtermenge (Guppe B) eingeteilt. Für die Analyse wurde ein Micro-CT (SkyScan 1072) verwendet. Ergebnisse: Gruppe A zeigte im Verlauf ab der 6. Lebenswoche ein signifikant höheres Körpergewicht als Gruppe B. Nach 20 Wochen betrug das Körpergewicht etwa das Doppelte. Statistisch signifikante Unterschiede zeigten sich zwischen beiden Gruppen im Körpergewicht $(A>B)$ und der Knochendichte $(B>A)$; im Micro-Ct war die Anzahl der Trabekel (Tb.N.) nur im proximalen Femur der Gruppe B erhöht. Einen signifikant weiteren Gelenkspalt des Hüftgelenkes zeigte sich in coronarer, sagittaler und transversaler Ebene der Gruppe A und im Kniegelenk in der coronaren Ebene, im transversalen Querdurchmesser und in der subchondralen Slerose. Signifikante Korrelationen konnten zwischen der Knochendichte und dem Querdurchmesser des Tibiaplateaus, zwischen der Anzahl der Trabekel des Hüft- und Kniegelenkes, dem Körpergewicht und zwischen der Anzahl der Trabekel des proximalen Femurs und dem Durchmesser des Hüftkopfes in coronarer, sagittaler und transversaler Ebene gefunden werden. Zusammenfassung: Bei Leptindefizienz nimmt die Knochendichte bei zunehmendem Körpergewicht $a b$. Eine signifikante Änderung der Gelenkspaltweite lässt sich jedoch in beiden Gruppen im Micro-CT nicht nachweisen.
Autoren: Hansjoerg Heep ${ }^{1}$, Alexander Wegner ${ }^{1}$, Sebastian Hofmeister ${ }^{1}$, Christian Wedemeyer ${ }^{1}$

Schlagworte: Leptin, Gelenkspalt, Mikro-CT, bomechanische Belastung

Keywords:leptin, joint space, microCT, biomechanical loading

Zitierweise dieses Beitrages: BIOmaterialien 2010; 11 (November) S. $31-36$

\begin{abstract}
Introduction
It is a known fact that body fat regulates bone metabolism by means of hormonal factors, and furthermore, that the effects of muscle and loading are signaling factors in mechanotransduction $[12,40]$. Leptin, a peptide hormone produced predominantly by white fat cells, is one of these hormonal factors [ 1 , $13,14,18,30,42]$. Leptin inhibits appetite; consequently, leptin deficiency induces obesity. With regard to bone metabolism it is not clear whether leptin is a stimulator or an inhibitor of bone growth. Some study authors noted a positive relationship between serum leptin levels and bone mineral density $[16,28]$,
\end{abstract}

'Department of Orthopaedics, University of Duisburg-Essen, Pattbergstr. 1-3, 45329 Essen whereas others observed a negative or no relationship $[4,33$, $24,29]$, which further confounds the interpretation of the effect of leptin on bone mass. Simha et al. concluded that the role played by leptin in bone metabolism in humans may depend on the stage of life [35]. This might explain its positive effect on bone formation in the early stages of development. Leptin is also known to increase both proliferation and differentiation of the chondrocyte population of skeletal growth centers in organ cultures $[23,26]$. All these findings strongly support the theory that leptin could stimulate bone growth in the early stages of life.

In a few recent reports the animal model was a useful surrogate to investigate the mechanism of leptin. Mice with deficiency of leptin (obese; ob/ob) or its receptor (diabetic; $\mathrm{db} / \mathrm{db}$ ) are obe- 
se [1]. Both leptin and its receptors were found in murine fetal cartilage and bone template, as well as in the growth plate [21]. Takeda et al. and Karsenty described the leptin-dependent central control of bone remodeling via the sympathetic nervous system $[18,19,36,37]$. The sterility of ob/ob mice should increase bone resorption and indeed, osteoclast numbers and the parameters of bone resorption did increase in ob/ob mice. Nevertheless, leptin-deficient mice have a higher bone mass than wild-type mice and completely correct their high bone mass by intracerebroventricular infusion of leptin at a rate that does not result in any detectable leak of leptin in general circulation [10].

In general, mechanical loading stress on bones causes tissue deformation within the bone and stimulates the bone to adapt and remodel, ultimately improving resistance to osteoporosis. While previous studies have shown that bone parameters improved with weight-bearing exercise in normal subjects, we were interested in the co-influence of biomechanical loading on body weight and bone metabolism in subjects with leptin deficiency. There is so far no agreement regarding the positive effect of leptin in the early stages of life.

The ability of three-dimensional micro-computed tomography to detect changes in a rat model was evaluated for bone mass $[2,9,22,27,32,34,38]$. It is a method to image, quantify and study trabecular bone and the bone remodeling [32].

After induction of osteoarthritis by drugs in the murine knee, Botter et al. showed that significant changes in subchondral bone architecture and could be detected and quantified in 3D using micro-CT analysis [5]. Ankle micro-CT analyses demonstrated bone destruction in a rat model [20].

The aim of this study was to investigate the differential effects of weight-bearing on joint space in mice without the stimulation of leptin.

\section{Materials and Methods \\ Animals}

C57BL/6J-Lep ${ }^{\text {ob }}$ (ob/ob) female mice were received from the Janvier Laboratory (Le Genest St Isle, France) at the age of five weeks. The animal experiment was approved by the local authorities according to the official guidelines.

The effects of dietary restriction in ob/ob and wild-type mice has been described in several studies $[7,15,25]$. The animals were housed one per cage with access to water ad libitum and a standard rodent diet (8640 Harlan Teklad 22/5[1]; Harlan Teklad, Madison, WI, USA) containing $1.13 \%$ calcium and $0.94 \%$ phosphorus. The animals were maintained under conditions of a twelve-hour light and dark cycle with the light switched on at 6.00 a.m.. Food intake and body weight were recorded daily. There were two experimental groups divided according to the provision of food. Group A included $20 \mathrm{ob} / \mathrm{ob}$ mice with access to food ad libitum, the other $20 \mathrm{ob} / \mathrm{ob}$ mice in Group B received a limited amount of food ( 6 gr. each day). All the animals were euthanized by mechanical procedure at the age of twenty weeks.

\section{Micro-CT}

A high resolution micro-CT (SkyScan 1072, Aartselaar, Belgium) was used to perform qualitative and quantitative analysis of the hip and knee. All samples were scanned by a commercially available microcomputed tomographic scanner at the Department of Cardiology of the West German Heart Centre at the University of Duisburg-Essen.

Technical specifications of the micro-CT

The micro-CT system is based on a scanner developed for high- resolution imaging [up to $4 \mu \mathrm{m}$ cubic voxels] of sample sizes up to $2 \mathrm{~cm}^{3}$. The scanner uses a field $\mathrm{x}$-ray tube with an $8 \mu \mathrm{m}$ spot-seize and expected lifetime of $>10,000$ hours. The tube is operated at between 20 and 100 kiloelectron volts and a current of up to 100 micro amperes. For scanning, the samples are placed between the micro-focus $\mathrm{X}$-ray source and a Charge-Coupled-Device (CCD) detector (matrix size: $1024 \times 1024$ pixels, field of view: $25 \mathrm{~mm}^{2}$ ). In order to prevent samples from moving during scanning, the limbs are placed in a tightly fitting rigid plastic tube. In the scanner's chamber the specimens are placed on a stack of computer-controlled precision stages which are rotated in equiangular steps of $0.9^{\circ}$ around an angle of $180^{\circ}$. When the object is placed between the X-ray source and the CCD-detector, the cone-beam of X-rays passes the object and then hits the CCD-detector producing $2 \mathrm{D}-\mathrm{X}$-ray images. A personal computer is used to control the scanner and store the CCD image data recorded at each angle of view during the scanning process.

\section{Tomographic image reconstruction}

The X-ray projection data of the scanned samples are then submitted to the resident reconstruction program (Cone-beam Reconstruction, Skyscan, Aartselaar, Belgium), which is based on a Feldkamp filtered back projection algorithm [43] resulting in a volume image of up to 10,243 voxels, each cubic voxel being 4-19 $\mu \mathrm{m}$ on one side, depending on how much of the specimen has to be imaged.

\section{Cancellous bone assessment by micro-CT}

The regions of interest (ROIs) from the proximal femur and tibia were selected for structural analysis of the cancellous bone. A cubic region of $0.5 \times 0.5 \times 0.5 \mathrm{~mm} 3$ in the metaphysis of the tibia was adjacent to ( $1 \mathrm{~mm}$ away from) the growth plate and femoral head. Trabecular thickness (Tb. Th) and trabecular number (Tb.N) were based directly on the 3-D data using medial axis transformation and distance transformation.

\section{Joint space measurement by micro-CT}

The center of the head of the hip was detected by "data viewer". The measurements were made in micrometers. The smallest joint space was measured from the longitudinal, sagittal and transversal slices of the center. The joint space of the knee was measured from the transverse and sagittal slices between the medial condyle and the tibial plateau.

\section{Statistical analysis}

The data were analyzed and assessed using SPSS software (version 15.0; SPSS Institute Inc, Chicago, USA). Descriptive statistics of all variables were determined including the mean and standard deviation of each group. The difference of all parameters between the two groups was assessed using the Student's $t$-Test because all parameters were normally distributed [which was tested using the Kolmogorov Smirnov test]. Pearson's correlation coefficient was used to assess the relationship between all the trabecular bone parameters of the femur and tibia. A value of $p<0.05$ was considered to be statistically significant.

\section{Results}

No death or health deterioration occurred during this study. The body weight at each time point in the two groups is shown in Figure 1.

Animals with an ad libitum diet (Group A) were found to increase body weight significantly at the age of six weeks in comparison with the lean mice (Group B). From this time point on, 


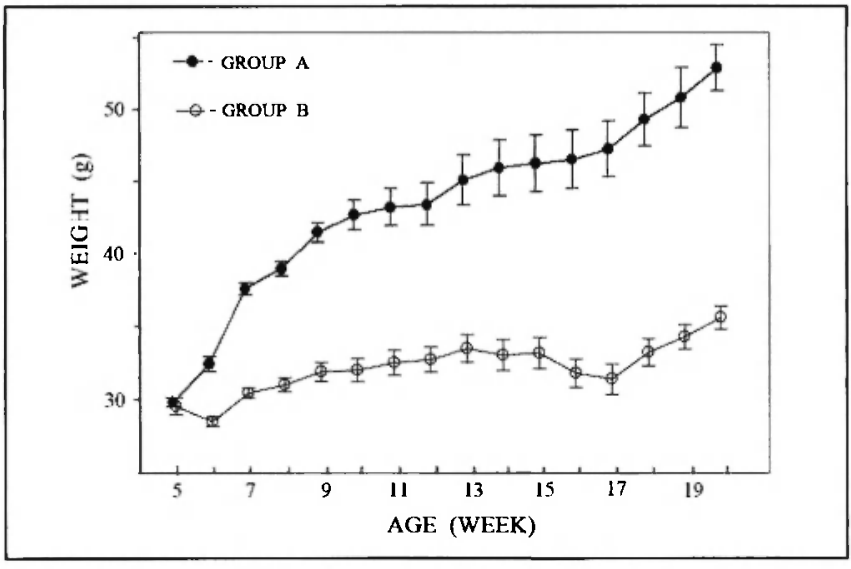

Fig. 1: The curves show the change in body weight in the two groups. The animals in Group $A$ had an ad libitum diet and reached a body weight of over 50 grams after 20 weeks, the animals in Group B with a controlled diet reached a body weight of over 35 grams after 20 weeks. Inter-group difference was already significant at the age of six weeks $(p<0.05)$.

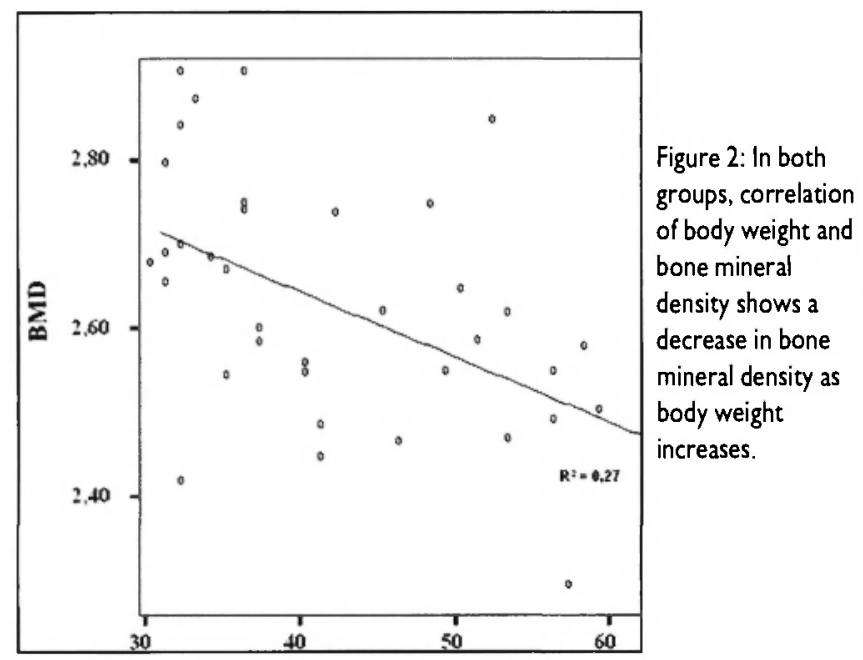

the difference increased constantly. At the age of twenty weeks the obese mice were almost twice as heavy as the lean mice. In both Group $A$ and Group $B$ the mice with a high body weight had a lower bone mineral density (BMD) (Figure 2) and a lower trabecular number (Tb.N) in the proximal femur and tibia (Table 1, Figure 3).

The animals with an ad libitum diet (Group A) were found to have a significantly increased joint space in the hip in the co-

Table 1: Statistically significant differences between the ad libitum diet Group A and controlled diet Group B for bone mineral density (BMD), body weight and trabecular number $(T b N)$ in the ROI of the proximal femur $(p<0.05)$ and the statistical trend of the trabecular number $(\mathrm{TbN})$ in the ROl of the proximal tibia $(\mathrm{P}=$ 0.058)

\begin{tabular}{|l|c|c|c|c|c|c|c|c|}
\hline Group & $\begin{array}{c}\text { BMD } \\
\text { mean }\end{array}$ & SD & $\begin{array}{c}\text { Weight (grams) } \\
\text { mean }\end{array}$ & SD & $\begin{array}{c}\text { TbN femur } \\
\text { mean }\end{array}$ & SD & $\begin{array}{c}\text { TbN tibia } \\
\text { mean }\end{array}$ & SD \\
\hline $\begin{array}{l}\text { Group A } \\
\text { (ad libitum diet) }\end{array}$ & 2.57 & 0.147 & 52.53 & 6.36 & 6.42 & 0.45 & 5.63 & 0.34 \\
\hline $\begin{array}{l}\text { Group B } \\
\text { (controlled diet) }\end{array}$ & 2.68 & 0.138 & 35.65 & 3.50 & 6.76 & 0.55 & 5.90 & 0.52 \\
\hline P value & $<0.05$ & & $<0.001$ & & 0.038 & & 0.058 & \\
\hline
\end{tabular}

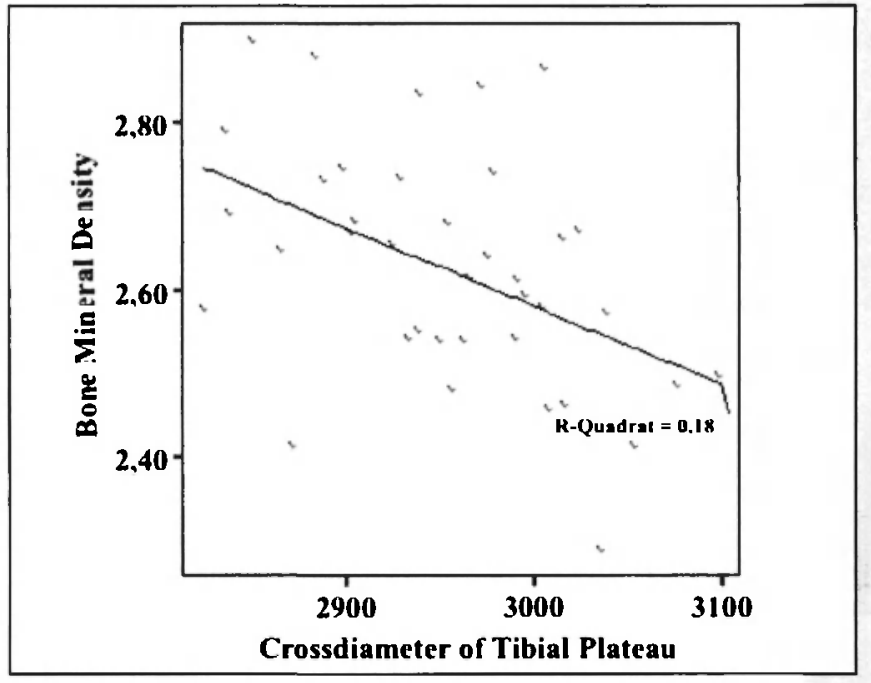

Figure 3: The correlation between bone mineral density and the cross-diameter of the tibial plateau shows that in both groups there was a significant decrease in bone mineral density as the cross-diameter of the tibial plateau increased $(p<0.01)$.

ronaly, sagittal and transverse planes in comparison with the lean mice (Group B) (Table 2).

The increase in the joint space in the knee in the coronary plane, for the transverse diameter of the tibial plateau and for the subchondral sclerosis in the ad libitum diet Group A was also statistically significant.

Only one significant correlation was found between bone mineral density (measured by micro-CT) and the cross-diameter of the tibial plateau (Figure 3).

Correlation was found between the trabecular number (Tb.N.) of the knee and femur (measured by micro-CT) and body weight (Fig. 4).

Correlation was also found between the trabecular number (Tb.N.) of the femur (measured by micro-CT) and the diameter of the femoral head in the sagittal, coronary and transverse planes (Fig. 5).

\section{Discussion}

The aim of the present study was to examine changes in the joint space induced by a response to biomechanical loading in leptin-deficient mice. Correlation of body weight and bone mineral density shows that in both groups bone mineral density decreased as body weight increased. However, this did not induce any significant changes in the joint space in either of the groups. Only one significant correlation was found between bone mineral density and the cross-diameter of the tibial plateau.

A great deal of research has confirmed that greater biomechanical loading due to high body weight contributes to the increased bone dimensions observed not only in our animal mo- 


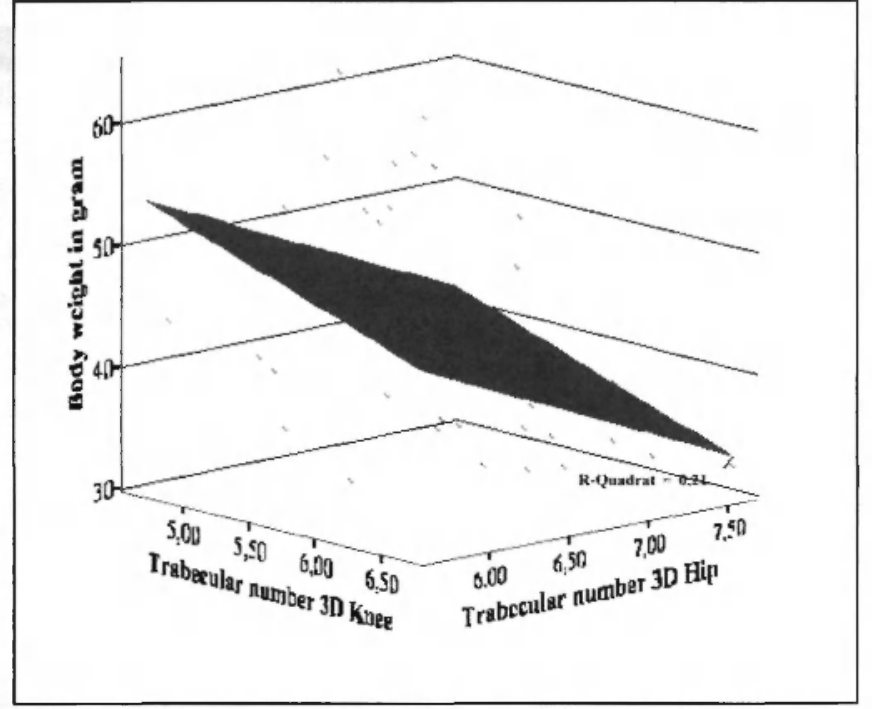

Figure 4: In both groups the correlation between the trabecular number (Tb.N.) and body weight shows a significant decrease in the trabecular number as body weight increases $(p<0.01)$.

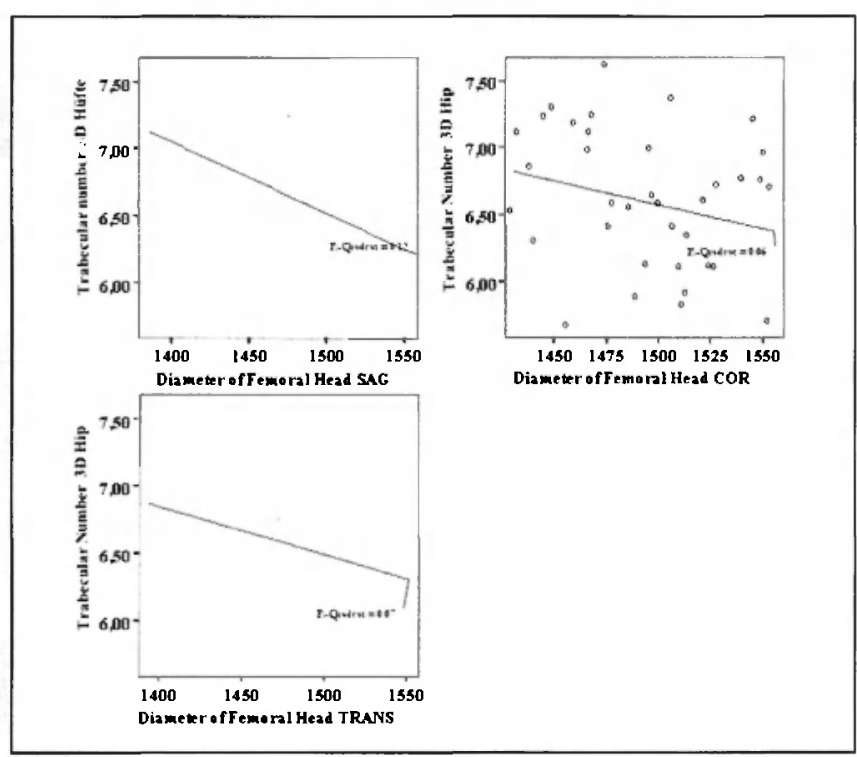

Figure 5: The correlation between the trabecular number (Tb.N.) of the femur and the diameter of the femoral head in the sagittal, coronary and transverse planes shows in both groups a significant decrease in the trabecular number as the diameter of the femoral head increases $(p<0,01)$.

Table 2: Statistically significant differences between the ad libitum diet Group A and the controlled diet Group B for joint space (JS) in the hip in the coronary, sagittal $(p<0.001)$ and transverse $(p<0.05)$ planes.

\begin{tabular}{|l|c|c|c|c|c|c|}
\hline Group & $\begin{array}{c}\text { JS } \\
\text { hip sag } \\
\text { mean }\end{array}$ & SD & $\begin{array}{c}\text { JS } \\
\text { hip cor } \\
\text { mean }\end{array}$ & SD & $\begin{array}{c}\text { JS } \\
\text { hip trans } \\
\text { mean }\end{array}$ & SD \\
\hline $\begin{array}{l}\text { Group A } \\
\text { (ad libitum diet) }\end{array}$ & 85.99 & 19.44 & 103.56 & 38.14 & 142.85 & 91.28 \\
\hline $\begin{array}{l}\text { Group B } \\
\text { (controlled diet) }\end{array}$ & 65.29 & 15.61 & 63.83 & 18.63 & 83.05 & 17.93 \\
\hline P value & $<0.001$ & & $<0.001$ & & $<0.05$ & \\
\hline
\end{tabular}

del but also in obese humans [11]. At the same time, it also contributes to an increased bone mass as a co-influence. Increased loading of long bones produces the greatest mechanical stress on the subperiosteal surface and stimulates bone formation by subperiosteal expansion [41]. A study of bone biomechanics in adult rats with diet-induced obesity showed significantly greater bone strength in the obese rats than in the controls [6]. Iwamoto et al. suggest that cancellous bone adaptation to treadmill exercise may be influenced by factors such as mechanical loading on the metaphyseal bone architecture in the young growing rat [17]. In a rat model of immobilisation osteoporosis Laib at al. measured the proximal part of the tibiae of the hind limbs in unloaded and control rats using 3D micro-CT. They show that most bone loss is caused by the thinning of the trabeculae, and to a lesser extent by a decrease in their number [5]. In the case of leptin-deficient mice our study shows in both groups a significant decrease in the trabecular number as the diameters of the femoral head increased.

With micro-CT it is possible to monitor prominent bony alterations such as osteophyte formation, trabecular remodeling, subchondral bone plate thickening, and subchondral sclerosis [39]. Furthermore, micro-CT arthrography is a novel technique for indirect visualization of the distinct features and structural analysis of the rat knee joint in small-animal research [31]. Botter et al. and Chappard at al. showed significant changes in subchondral bone architecture after induction of osteoarthritis or in advanced osteoarthritis [5, 8]. Only Batiste et al. demonstrated progressive cartilage degeneration and bone changes using 4-T MRI and micro-CT correlated to macroscopic grading [3]. However, none of these authors described the changes which take place in the joint space in hips and knees affected by osteoarthritis.

In summary, biomechanical loading leads to reduced bone mineral density due to a decrease in the number of trabeculae. Decreased body weight in leptin-deficient mice protects the mice against bone loss. This finding is consistent with the principle of the light-weight construction of bone. With micro-CT is it not possible to demonstrate changes in joint space in response to biomechanical loading. Differences in cartilage and the bone in joint spaces will be examined in later studies correlated to histomorphology. It is not possible to conclude that these results also apply to human beings.

\section{Abstract}

Leptin was regulate bone development. However, there is so far no agreement concerning the effect of leptin in the early stages of life. The aim of this study was to investigate the differential effects of weight-bearing on joint space in leptin-deficiency mice. Materials, Methods and Results: C57BL/6J-Lep ${ }^{\circ b}$ (ob/ob) female mice with an ad-libitum-diet (Group A) were found to increase body weight significantly at the age of six weeks in comparison with lean mice (Group B). At the age of twenty weeks the obese mice were almost twice as heavy as the lean mice. A high resolution micro-CT (SkyScan 1072) was used to perform qualitative and quantitative analysis of the hip and knee. Significant statistical differences are shown between the two groups for body weight and bone mineral density, for the trabecular number (Tb.N.) for the proximal femur, a increased joint space in the hip in the coronary, sagittal and transverse planes for Group $\mathrm{A}$, a increase in the joint space in the knee in the coronary plane, for the transverse diameter of the tibial plateau and for the subchondral sclerosis. Significant correlation was found between bone mineral density and the cross diameter of tibial plateau, between Tb.N. of knee/fe- 
mur and body weight, between Tb.N. of femur and diameter of the femoral head in the sagittal, coronary and transverse planes.

\section{Conclusion}

In both groups decreased bone mineral density as body weight increased. However, this did not induce any significant changes in the joint space in either of the groups in micro-CT.

\section{Literature}

[1] Ahima RS, Flier JS: Leptin. Annu Rev Physiol 62:413-37, 2000

[2] Barou O, Valentin D, Vico L, Tirode C, Barbier A, Alexandre C, Lafage-Proust MH: High-resolution three-dimensional micro-computed tomography detects bone loss and changes in trabecular architecture early: comparison with DEXA and bone histomorphometry in a rat model of disuse osteoporosis. Invest Radiol 37:40-6, 2002

[3] Batiste DL, Kirkley A, Laverty S, Thain LM, Spouge AR, Holdsworth DW: Ex vivo characterization of articular cartilage and bone lesions in a rabbit ACL transection model of osteoarthritis using MRI and micro-CT. Osteoarthritis Cartilage 12:986-96, 2004

[4] Blum M, Harris SS, Must A, Naumova EN, Phillips SM, Rand WM, Dawson-Hughes B: Leptin, body composition and bone mineral density in premenopausal women. Calcif Tissue

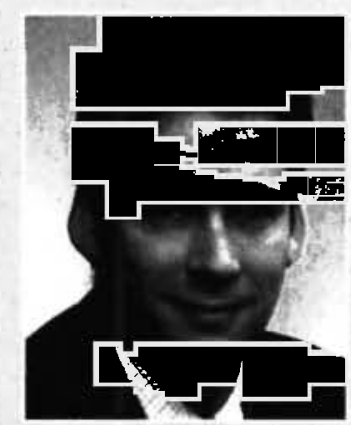

\section{Dr. med. Hansjoerg Heep}

Korrespondenzadresse: Department of Orthopaedics, University of Duisburg-Essen Pattbergstr. 1-3 D-45329 Essen hansjoerg.heep@uni-due.de Phone.: 0201/4089-2147

Fax: $0201 / 4089-2722$

\section{Akademischer Lebenslauf}

Oberarzt, Orthopädische Klinik der Universität DuisburgEssen im Evangel. Krankenhaus Essen-Werden

1986-1988 Studium der Chemie Universität Heidelberg

1988-1994 Studium der Humanmedizin Heidelberg und München (LMU, Sommersemester 1988)

Dissertation "Quantifizierung der RESClearance nach Reperfusion bei Lebertransplantation unter klinischen Bedingungen $^{\text {" }}$

2001

2003 Facharzt Chirurgie

2006 Schwerpunkt Unfallchirurgie

2007 Facharzt Orthopädie und Unfallchirurgie Zusatzbezeichnung Spezielle Orthopädische Chirurgie, Physikalische Therapie dorf Orthopädie Universität Duisburg-Essen
Int 73:27-32, 2003

[5] Botter SM, van Osch GJ, Waarsing JH, Day JS, Verhaar JA, Pols HA, van Leeuwen JP, Weinans H: Quantification of subchondral bone changes in a murine osteoarthritis model using micro-CT. Biorheology 43:379-88, 2006

[6] Brahmabhatt V, Rho J, Bernardis L, Gillespie R, Ziv I: The effects of dietary-induced obesity on the biomechanical properties of femora in male rats. Int J Obes Relat Metab Disord 22:813-8, 1998

[7] Brochmann EJ, Duarte ME, Zaidi HA, Murray SS: Effects of dietary restriction on total body, femoral, and vertebral bone in SENCAR, C57BL/6, and DBA/2 mice. Metabolism 52:126573, 2003

[8] Chappard C, Peyrin F, Bonnassie A, Lemineur G, Brunet-Imbault B, Lespessailles E, Benhamou CL: Subchondral bone micro-architectural alterations in osteoarthritis: a synchrotron micro-computed tomography study. Osteoarthritis Cartilage $14: 215-23,2006$

[9] Ding M, Odgaard A, Hvid I: Changes in the three-dimensional microstructure of human tibial cancellous bone in early osteoarthritis. J Bone Joint Surg Br 85:906-12, 2003

[10] Ducy P, Amling M, Takeda S, Priemel M, Schilling AF, Beil FT, Shen J, Vinson C, Rueger JM, Karsenty G: Leptin inhibits bone formation through a hypothalamic relay: a central control of bone mass. Cell 100:197-207, 2000

[11] Felson DT, Zhang Y, Hannan MT, Anderson JJ: Effects of weight and body mass index on bone mineral density in men and women: the Framingham study. J Bone Miner Res 8:56773, 1993

[12] Gross TS, Srinivasan S, Liu CC, Clemens TL, Bain SD: Noninvasive loading of the murine tibia: an in vivo model for the study of mechanotransduction. J Bone Miner Res 17:493501,2002

[13] Hamrick MW, Ding KH, Pennington C, Chao YJ, Wu YD, Howard B, Immel D, Borlongan C, McNeil PL, Bollag WB, Curl WW, Yu J, Isales CM: Age-related loss of muscle mass and bone strength in mice is associated with a decline in physical activity and serum leptin. Bone 39:845-53, 2006

[14] Hamrick MW, Ferrari SL: Leptin and the sympathetic connection of fat to bone. Osteoporos Int, 2007

[15] Hsieh EA, Chai CM, Hellerstein MK: Effects of caloric restriction on cell proliferation in several tissues in mice: role of intermittent feeding. Am J Physiol Endocrinol Metab 288:E96572, 2005

[16] Iwamoto J, Takeda T, Ichimura S: Effect of exercise on tibial and lumbar vertebral bone mass in mature osteopenic rats: bone histomorphometry study. J Orthop Sci 3:257-63, 1998 [17] Iwamoto J, Yeh JK, Aloia JF: Differential effect of treadmill exercise on three cancellous bone sites in the young growing rat. Bone 24:163-9, 1999

[18] Karsenty G: Convergence between bone and energy homeostases: leptin regulation of bone mass. Cell Metab 4:3418, 2006

[19] Karsenty G: Leptin controls bone formation through a hypothalamic relay. Recent Prog Horm Res 56:401-15, 2001

[20] Kliwinski C, Kukral D, Postelnek J, Krishnan B, Killar L, Lewin A, Nadler S, Townsend R: Prophylactic administration of abatacept prevents disease and bone destruction in a rat model of collagen-induced arthritis. J Autoimmun 25:165-71, 2005

[21] Kume K, Satomura K, Nishisho S, Kitaoka E, Yamanouchi $\mathrm{K}$, Tobiume S, Nagayama M: Potential role of leptin in endochondral ossification. J Histochem Cytochem 50:159-69, 2002 [22] Laib A, Barou 0, Vico L, Lafage-Proust MH, Alexandre C, Rugsegger P: 3D micro-computed tomography of trabecular and cortical bone architecture with application to a rat model 
of immobilisation osteoporosis. Med Biol Eng Comput 38:32632,2000

[23] Maor G, Rochwerger M, Segev Y, Phillip M: Leptin acts as a growth factor on the chondrocytes of skeletal growth centers. J Bone Miner Res 17:1034-43, 2002

[24] Martini G, Valenti R, Giovani S, Franci B, Campagna S, Nuti R: Influence of insulin-like growth factor- 1 and leptin on bone mass in healthy postmenopausal women. Bone 28:113-7, 2001

[25] Murase T, Mizuno T, Omachi T, Onizawa K, Komine Y, Kondo H, Hase T, Tokimitsu I: Dietary diacylglycerol suppresses high fat and high sucrose diet-induced body fat accumulation in C57BL/6J mice. J Lipid Res 42:372-8, 2001

[26] Nakajima R, Inada H, Koike T, Yamano T: Effects of leptin to cultured growth plate chondrocytes. Horm Res 60:91-8, 2003

[27] Nuzzo S, Peyrin F, Cloetens P, Baruchel J, Boivin G: Quantification of the degree of mineralization of bone in three dimensions using synchrotron radiation microtomography. Med Phys 29:2672-81, 2002

[28] Odabasi E, Ozata M, Turan M, Bingol N, Yonem A, Cakir B, Kutlu M, Ozdemir IC: Plasma leptin concentrations in postmenopausal women with osteoporosis. Eur J Endocrinol 142:170-3, 2000

[29] Rauch F, Blum WF, Klein K, Allolio B, Schonau E: Does leptin have an effect on bone in adult women? Calcif Tissue Int 63:453-5, 1998

[30] Reid IR: Relationships between fat and bone. Osteoporos Int, 2007

[31] Roemer FW, Mohr A, Lynch JA, Meta MD, Guermazi A, Genant HK: Micro-CT arthrography: a pilot study for the ex vivo visualization of the rat knee joint. AJR Am J Roentgenol 184:1215-9, 2005

[32] Ruegsegger P, Koller B, Muller R: A microtomographic system for the nondestructive evaluation of bone architecture. Calcif Tissue Int 58:24-9, 1996

[33] Sato M, Takeda N, Sarui H, Takami R, Takami K, Hayashi M, Sasaki A, Kawachi S, Yoshino K, Yasuda K: Association between serum leptin concentrations and bone mineral density, and biochemical markers of bone turnover in adult men. $J$ Clin Endocrinol Metab 86:5273-6, 2001

[34] Schmidt C, Priemel M, Kohler T, Weusten A, Muller R, Amling M, Eckstein F: Precision and accuracy of peripheral quantitative computed tomography [pQCT] in the mouse skeleton compared with histology and microcomputed tomography [microCT]. J Bone Miner Res 18:1486-96, 2003

[35] Simha V, Zerwekh JE, Sakhaee K, Garg A: Effect of subcutaneous leptin replacement therapy on bone metabolism in patients with generalized lipodystrophy. J Clin Endocrinol Metab 87:4942-5, 2002

[36] Takeda S: Central control of bone remodeling. Biochem Biophys Res Commun 328:697-9, 2005

[37] Takeda S, Elefteriou F, Levasseur R, Liu X, Zhao L, Parker KL, Armstrong D, Ducy P, Karsenty G: Leptin regulates bone formation via the sympathetic nervous system. Cell 111:30517,2002

[38] Waarsing JH, Day JS, van der Linden JC, Ederveen AG, Spanjers C, De Clerck N, Sasov A, Verhaar JA, Weinans H: Detecting and tracking local changes in the tibiae of individual rats: a novel method to analyse longitudinal in vivo microCT data. Bone 34:163-9, 2004

[39] 39. Wachsmuth L, Engelke K: High-resolution imaging of osteoarthritis using microcomputed tomography. Methods Mol Med 101:231-48, 2004

[40] Warner SE, Sanford DA, Becker BA, Bain SD, Srinivasan $S$, Gross TS: Botox induced muscle paralysis rapidly degrades bone. Bone 38:257-64, 2006

[41] Zhang P, Yokota H: Effects of surgical holes in mouse tibiae on bone formation induced by knee loading. Bone 40:1320-8, 2007

[42] Zhang Y, Proenca R, Maffei M, Barone M, Leopold L, Friedman JM: Positional cloning of the mouse obese gene and its human homologue. Nature 372:425-32, 1994

[43] Zhao S, Yu H, Wang G: A unified framework for exact cone-beam reconstruction formulas. Med Phys 32:1712-21, 2005 